\title{
COMPARISON OF OLFACTORY DISTURBANCE IN COVID-19 POSITIVE CASES WITH NON COVID-19 RHINITIS CASES
}

\author{
Zeeshan Ayub Sheikh, Azeema Ahmed, Ahmed Hasan Ashfaq*, Naeem Riaz**, Naveed Ahmed ${ }^{* * *}$, Naeema Ahmed ${ }^{* * * *}$ \\ Combined Military Hospital Quetta/National University of Medical Sciences (NUMS) Pakistan, *Benazir Bhutto Hospital, Rawalpindi Pakistan, **Pakistan Naval \\ Ship, Hafeez Islamabad Pakistan, ${ }^{* * *}$ Combined Military Hospital Sibi/National University of Medical Sciences (NUMS) Pakistan, ${ }^{* * *}$ Army Medical \\ College/National University of Medical Sciences (NUMS) Rawalpindi Pakistan
}

\begin{abstract}
Objective: To determine association of anosmia as an early symptom of COVID-19 infection. Study Design: Comparative cross sectional study. Place and Duration of Study: ENT department, Combined Military Hospital, Quetta, from Apr to Oct 2020. Methodology: A total of 6411 consenting patients with symptoms of viral upper respiratory tract infection presenting at ENT department, Combined Military Hospital Quetta, from Apr to Oct 2020 were tested for COVID 19 via PCR studies.

Results: Out of 6411 individuals 1109 (17.3\%) were found to be COVID positive and 5302 (82.7\%) were COVID negative. Of the COVID positive cases 611 (55.1\%) of COVID positive individuals had anosmia, whereas only 68 (1.2\%) of COVID negative individuals had anosmia, this observation was statistically significant ( $p<0.001$ on chi square test). Whereas only 33 ( $2.9 \%)$ patients had nasal obstruction in COVID positive group, and $68(1.2 \%)$ cases in COVID negative group had nasal obstruction, this observation was not statistically significant ( $p>0.05$ on chi square test).
\end{abstract}

Conclusion: Anosmia has a definite association with COVID 19 infection.

Keywords: Anosmia, COVID-19, Olfactory cells.

This is an Open Access article distributed under the terms of the Creative Commons Attribution License (http://creativecommons.org/licenses/by/4.0), which permits unrestricted use, distribution, and reproduction in any medium, provided the original work is properly cited.

\section{INTRODUCTION}

The emergence of corona virus zoonotic disease that originated in Wuhan China has now evolved into a pandemic involving $>200$ countries around the globe, with a second wave of the disease well under way. World Health Organization (WHO) has coined an official nomenclature for this disease, i.e. corona virus disease 2019, or COVID-191.

International Committee on Taxonomy of Viruses (ICTV) has concluded after extensive research the virus is in fact a new type of coronavirus (Coronaviridae), a Ribonucleic acid (RNA) virus ${ }^{2}$. The virus is thought to have been a cross infection from Bats to Humans originating from China and is specifically a new type of severe acute respiratory syndrome-related coronavirus. WHO and ICTV have officially named this novel virus as severe acute respiratory syndrome coronavirus 2 , or SARS-CoV-2 3 .

The disease has an initial rather asymptomatic period with subsequent rapid progress of the infection which results in involvement of multiple organs due to Bradykinin deregulation. This postulation has led to aneffortto identify the disease in its early stages to prevent spread by quarantine and to start treatment at the earliest ${ }^{4}$. Most of the World is now coping with a

Correspondence: Dr Zeeshan Ayub Sheikh, Classified ENT Specialist, Combined Military Hospital, Quetta Pakistan

Received: 15 Oct 2020; revised received: 23 Dec 2020; accepted: 29 Dec 2020 second wave of the disease, with countries like Spain experiencing a hard hitting-second wave with nearly double the cases per week of first wave of COVID-19 infection ${ }^{5}$. With identification of the virus and its spread and infectivity pattern it has become obvious that early detection and thereby contact limitation and early treatment is the only hope to curtail the virus till development of an effective vaccine. Anosmia and smell disturbance has been quoted as initial symptom of COVID-19. As with other Flu viruses, COVID-19 is primarily transmitted by respiratory route, thereby adding Anosmia to the early diagnostic criteria especially when the patient is relatively asymptomatic and in the most infective stage, and detection of the disease at this stage serves two purposes i.e. one to isolate the infected person immediately to limit the spread and second to initiate treatment at the earliest to prevent mortality and morbidity ${ }^{6}$. Corona, Picorna, Respiratory Synsitial and Influenza viruses start with respiratory transmission to nasal and para nasal sinus mucosa. It is postulated that initial 50 replications of the virusoccur in nasal mucosa ${ }^{7}$. As is associated with other viral infections of nose, three postulated mechanisms of anosmia are under discussion; that edema leads to engorgement of nasal mucosa and turbinates leading to blockage of air circulation in area of respiratory epithelium (located anterio-superiorly in Nasal roof) and that during viral replication process the olfactory organs ofolfactory mucosa aredamaged thereby leading to anosmia 
or hyposmia, and thirdly that virus damages sustentacular cells supporting the Olfactory epithelium. The loss of support cells negatively affects the function of olfactory epithelium resulting in anosmia ${ }^{8}$.

Many patients of anosmia also complain of loss or change of taste. Regarding dysguesia smell plays a vital role in appreciating taste of food, so any loss or alteration of smell can lead to taste disturbances ${ }^{9}$. The same phenomenon occurs in all other viral rhinitis and olfactory disturbance is a predominant symptom ${ }^{10}$. The need is to study smell disorder as a symptom in COVID-19 positive and COVID-19 Negative patients to understand if anosmia can be used as a first symptom to educate the masses the need for isolation and testing in individuals with anosmia, as with early diagnosis isolation of the patient in the most infective stage is possible.

\section{METHODOLOGY}

This study was done to find ifolfactory disturbance i.e. anosmia has an associationwith COVID-19 Positivity status of patients, and also to determine association of anosmia with symptoms of viral upper respiratory tract infection among the same study group at ENT Department, Combined Military Hospital Quetta, from April to October 2020.

A total of 6411 stable patients with no or mild symptoms forwarded to hospital laboratory from screening clinic for COVID-19 testing were verbally informed of the study and consented. These individuals were asked leading questions about nasal symptoms and smell disorder in a language the patient could understand. Nasopharyngeal and Oral samples were taken of each patient in Viral Transport medium and subsequently Polymerase Chain Reaction PCR was performed for viral Ribonucleic acid (RNA) detection. Any patient with severe respiratory symptoms, oxygen dependency or high grade fever was not included, also any individual with previous history of nasal surgery was also excluded. COVID Status of patients was detected using polymerase chain reaction (PCR) of viral RNA using COBAS 6800 systems of Roche Molecular Systems. Detection of viral genome up to 30 cycles of PCR was taken as positive. The COBAS SARS-Cov-2 isa single well dual target assay which involves qualitative detection of SARS-CoV-2 virus in the sample in areal time RT-PCR platform. The COBAS system has a full process positive control, negative control and internal control.

On basis of results of COVID-19 PCR testing patients were purpose divided into Covid Positive and
Covid Negative. Treatment of all COVID POSITIVE individuals was started by Hospital Medical Team as per WHO guidelines. Statistical analysis was carried out on SPSS version 17. Chi Square test wasapplied to compare Anosmia Status amongst COVID Groups. $p$ value less than 0.05 was considered to be significant.

\section{RESULTS}

A total of 6411 adult patients volunteered for the study, $1109(17.3 \%)$ patients fell into COVID positive and $5302(82.7 \%)$ in COVID negative group. Age varied from 19-65 years with mean age $38.93 \pm 13.2$ years. Gender distribution is given in table-I.

Table-I: Gender distribution.

\begin{tabular}{|c|c|c|c|}
\hline \multirow[b]{2}{*}{ Gender } & \multicolumn{3}{|c|}{ COVID Status } \\
\hline & $\begin{array}{c}\text { COVID +ve } \\
\mathrm{n}=1109(17.3 \%)\end{array}$ & \multicolumn{2}{|c|}{$\begin{array}{c}\text { COVID -ve } \\
n=5302(82.7 \%)\end{array}$} \\
\hline Female & $405(36.6 \%)$ & \multicolumn{2}{|c|}{$2060(38.2 \%)$} \\
\hline Male & $704(63.4 \%)$ & \multicolumn{2}{|c|}{$3242(61.1 \%)$} \\
\hline \multicolumn{4}{|c|}{ Table-II: Statistical analysis (chi square test). } \\
\hline \multirow{2}{*}{$\begin{array}{l}\text { Olfactory } \\
\text { Diturbance }\end{array}$} & \multicolumn{2}{|c|}{ COVID Status $(n=6411)$} & \multirow[b]{2}{*}{$\begin{array}{c}p- \\
\text { value }\end{array}$} \\
\hline & $\begin{array}{c}\text { COVID +ve } \\
n=1109(17.3 \%)\end{array}$ & $\begin{array}{c}\text { COVID -ve } \\
n=5302(82.7 \%)\end{array}$ & \\
\hline \multicolumn{4}{|c|}{ Anosmia/ Hyposmia } \\
\hline $\begin{array}{l}\text { Present } \\
\text { Absent }\end{array}$ & $\begin{array}{l}611(55.1 \%) \\
498(44.9 \%)\end{array}$ & $\begin{array}{c}68(1.2 \%) \\
5234(98.8 \%) \\
\end{array}$ & $<0.001$ \\
\hline \multicolumn{4}{|c|}{ Nasal Blockage } \\
\hline $\begin{array}{l}\text { Present } \\
\text { Absent }\end{array}$ & $\begin{array}{c}33(2.9 \%) \\
1076(97.1 \%)\end{array}$ & $\begin{array}{c}68(1.3 \%) \\
5234(98.7 \%) \\
\end{array}$ & $>0.05$ \\
\hline
\end{tabular}

In 1109 cases of COVID positive group, 611 (55.1\%) individuals had anosmia. In this group 33 $(2.9 \%)$ patients had nasal obstruction, out of these 33 $(2.9 \%)$ patients only $20(1.8 \%)$ had anosmia.

In 5302 cases of COVID negative group only $68(1.2 \%)$ individuals had anosmia. In this group 68 $(1.2 \%)$ cases had nasal obstruction, and out of these $68(1.2 \%)$ cases only $62(1.1 \%)$ had anosmia, as seen in figure.

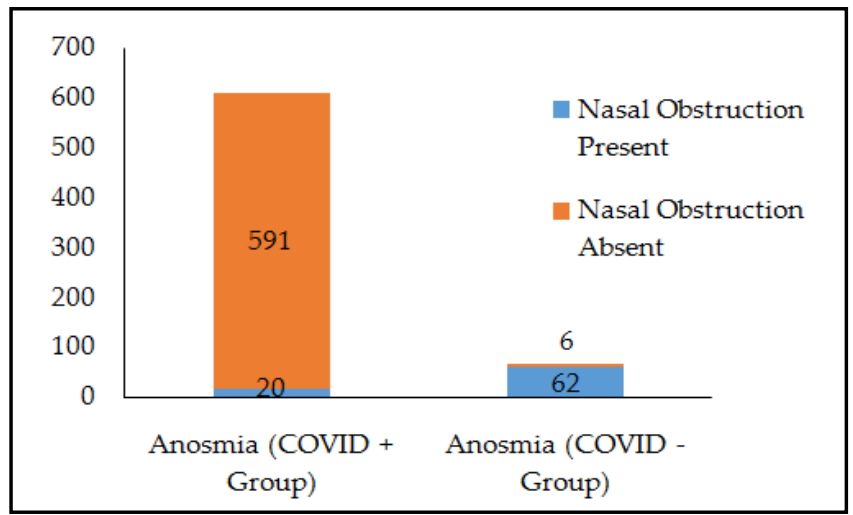

Figure: Relation of nasal blockage to anosmia. 
$p<0.001$ was achieved on chi square test that was applied to test significance of Olfactory disturbance in correlation with COVID status as shown in table-II. Whereas as nasal obstruction had no significant correlation with COVID Status $(p>0.05)$ as shown in table-II. The result of chi square test shows that COVID positive status has a definite positive association to olfactory disturbance i.e. anosmia.

\section{DISCUSSION}

Anosmia in patients of COVID-19 infection can occur due to mechanical obstruction of airflow to olfactory cleft, destruction of olfactory epithelium and loss of olfactory sustentacular cells. Olfactory cleft is an area lining anteriorly and superior portion of nasal roof with cribriform plate as the upper limit. Olfactory cleft has the olfactory receptors as second order neurons. Airflow obstruction to the olfactory cleft is a result of mechanical obstruction by inflamed nasal turbinate's and nasal mucosa which is characterized by nasal blockage. It has been reported that most of Covid positive patients who complain of anosmia do not have accompanying nasal obstruction ${ }^{11}$.

The second postulated mechanism is destruction of olfactory receptors in olfactory cleft. Although a transient phenomenon, it is mostly seen in viral infections of nose and paranasal sinuses. However, when olfactory mucosa of COVID-19 positive patients was examined no damage to olfactory receptors was seen. Recently a third postulated mechanism reported by post mortem exam of COVID patients showed loss of sustentacular cells in the olfactory region. Loss of sustentacular or support cells bends the olfacatory receptors leading to altered signal reception and processing and might lead to smell disturbances ${ }^{12}$.

Kaye et al, postulated extension of viral RNA into the respiratory mucosa via Angiotensin Converting Enzyme 2 and further expansion to olfactory cleft leading to epithelial dysfunction. This disruption is time limiting with signal processing reverting to normal after resolution of Covid infection after varying time, which explains the regain of olfactory sensation following recovery from Covid infection ${ }^{13}$. Clair et al, in a peer-reviewed workup of Covid infected cases have designated Covid related anosmia as "Isolated Sudden -Onset Anosmia (ISOA)" designating Covid associated anosmia as a novel syndrome ${ }^{14}$.

Data collected showed a statistically significant association of anosmia in Covid Positive individuals as compared to Covid Negative cases. In Covid Positive Group no correlation was found between anosmia and nasal blockage, whereas a positive correlation was found between Nasal blockage and anosmia in Covid Negative group.

All the patients in the study were those that did not have severe symptoms or required oxygen at time of testing. Route of entry of COVID-19 virus is nasal passage with first fifty replications occurring in nasal mucosa. Thereby nasal symptoms i.e. anosmia should logically be the first symptom for all infected patients. Testing healthy individuals with unexplained sudden onset smell disturbance can be of significance in two ways. Firstly, it will help to identify at risk group who can be isolated till Covid testing as spread of virus is maximum in asymptomatic stage. Secondly earlier identification leads to early treatment and monitoring of patient so that the patient is helped before landing into respiratory problems.

Moein in a case control study, concluded that patients having anosmia during the pandemic had $94 \%$ chance of being Covid positive. Also patients with preexisting history of allergic rhinitis had an increased chance of developing COVID related anosmia. This study was carried out on 120 individuals with 60 cases and 60 as control. So, in the current scenario of Covid Pandemic ENT Surgeons can play their part by educating the population not to ignore sudden onset unexplained anosmia, and if present such individuals should isolate themselves with Covid testing ${ }^{15}$.

Klopfenstein in a short communication, studied 54 Covid positive patients with anosmia. His analysis showed presence of predominantly anosmia and other nasal symptoms such as dysguesia, rhinorrhea and nasal blockage prior to development of fever or respiratory symptoms. Therefore identifying sudden, unexplained onset nasal symptoms without fever warrants isolation and Covid testing ${ }^{16}$.

Varia et al in a rapid communication concluded that combined anosmia and ageusia have a high predictive value in diagnosing COVID-19 infection in general population of Italy. With communicating the findings to health authorities' case identification and contact listing was vastly improved ${ }^{17}$. Menni et al, studied 1,573,103 individuals via an app called "COVID RADAR" with real time patient reporting of signs and symptoms as well as progression of illness. The came to the conclusion that combined anosmia and ageusia had a positive predictive value of $61.7 \%$. Presence of combined anosmia, ageusia, cough, abdominal discomfort, loose stools and anorexia as a strong predictor of COVID-19 infection. Thus a combination of above- 
mentioned symptoms is an alarming situation and should alert health care workers to identify COVID-19 cases and educate masses for general awareness of disease $^{18}$. Iravani et al, in a Swedish study, of 2440 individuals who volunteered information about anosmia via a website, further these individuals were tested for anosmia with five group of common odors with COVID-19 PCR testing. They arrived at the conclusion that there was a statistically significant decline in Odor perception in COVID-19 patients as compared to uninfected population ${ }^{19}$.

\section{CONCLUSION}

Anosmia or smell related symptoms could be used as guiding symptom for early detection and testing individuals infected with for COVID-19.

\section{CONFLICT OF INTEREST}

This study has no conflict of interest to be declared by any authors.

\section{REFERENCES}

1. Cui J, Li F, Shi ZL. Origin and evolution of pathogenic coronaviruses. Nat Rev Microbiol 2019; 17(3): 181-92.

2. Coronaviridae study group of the international committee on taxonomy of viruses. the species severe acute respiratory syndrome-related coronavirus: classifying $2019-\mathrm{nCoV}$ and naming it SARS-CoV-2. Nat Microbiol 2020; 5(4): 536-44.

3. Gengler I, Wang JC, Speth MM, Sedaghat AR. Sinonasal pathophysiology of SARS CoV-2 and COVID-19: A systematic review of the current evidence. Laryngoscope Investig Otolaryngol 2020; 5(3): 354-59.

4. Wang D, Hu B, Hu C, Zhu F, Liu X, Zhang J, et al. Clinical characteristics of 138 hospitalized patients with 2019 novel coronavirus-infected pneumonia in Wuhan. China JAMA 2020; 323(11): 1061-69.

5. Huang C, Wang Y, Li X, Ren L, Zhao J, Hu Y, et al. Clinical features of patients infected with 2019 novel coronavirus in Wuhan, China Lancet 2020; 395(10223): 497-06.

6. Wu D, Wu T, Liu Q, Yang Z. The SARS-CoV-2 outbreak: what we know. Int J Infect Dis 2020; 94(1): 44-48.

7. Wang Z, Yang B, Li Q, Wen L, Zhang R. Clinical features of 69 cases with coronavirus disease 2019 in Wuhan, China. Clin Infect Dis 2020; 71(15): 769-77.

8. Giacomelli A, Pezzati L, Conti F, Bernacchia D, Siano M, Oreni $\mathrm{L}$, et al. Self-reported olfactory and taste disorders in patients with severe acute respiratory coronavirus 2 infection: a crosssectional study. Clin Infect Dis 2020; 71(15): 889-90.

9. Wu J, Liu J, Zhao X, Liu C, Wang W, Wang D, et al. Clinical Characteristics of Imported Cases of Coronavirus Disease 2019 (COVID-19) in Jiangsu Province: A Multicenter Descriptive Study. Clin Infect Dis 2020; 71(15): 706-12.

10. Aksoy C, Elsürer C, Artac H, Bozkurt MK. Evaluation of olfactory function in children with seasonal allergic rhinitis and its correlation with acoustic rhinometry. Int J Pediatr Otorhinolaryngol 2018; 113(1): 188-91.

11. Vaira LA, Deiana G, Fois AG, Pirina P, Madeddu G, De Vito A, et al. Objective evaluation of anosmia and ageusia in COVID-19 patients: Single center experience on 72 cases. Head Neck 2020; 42(6): 1252-58.

12. Lechien JR, Chiesa-Estomba CM, De Siati DR, Horoi M, Le Bon $\mathrm{SD}$, Rodriguez A, et al. Olfactory and gustatory dysfunctions as a clinical presentation of mild-to-moderate forms of the coronavirus disease (COVID-19): a multicenter European study. Eur Arch Otorhinolaryngol 2020; 277(8): 2251-61.

13. Kaye R, Chang CD, Kazahaya K, Brereton J, Denneny III JC. COVID-19 anosmia reporting tool: initial findings. Otolaryngol Head Neck Surg 2020; 163(1): 132-34.

14. Gane SB, Kelly C, Hopkins C. Isolated sudden onset anosmia in COVID-19 infection. A novel syndrome. Rhinol 2020; 58(3): 299301.

15. Moein ST, Hashemian SM, Mansourafshar B, Khorram Tousi A, Tabarsi P, Doty RL. Smell dysfunction: a biomarker for COVID19. Int Forum Allergy Rhinol 2020; 10(8): 944-50.

16. Klopfenstein T, Toko L, Royer PY, Lepiller Q, Gendrin V, Zayet S. Features of anosmia in COVID-19. Med Mal Infect 2020; 50(5):436-39.

17. Vaira LA, Salzano G, Deiana G, De Riu G. Anosmia and ageusia: common findings in COVID-19 patients. Laryngoscope 2020; 130(1): 1787-87.

18. Menni C, Valdes A, Freydin MB, Ganesh S, Moustafa JE, Visconti A, et al. Loss of smell and taste in combination with other symptoms is a strong predictor of COVID-19 infection. Med Rxiv 2020; $1(1): 1-22$.

19. Iravani B, Arshamian A, Ravia A, Mishor E, Snitz K, Shushan S, et al. Relationship between odor intensity estimates and COVID19 population prediction in a Swedish sample. Med Rxiv 2020; 1(1): 1-14. 